Article

\title{
Ambidextrous Marketing Capabilities, Exploratory and Exploitative Market-Based Innovation, and Innovation Performance: An Empirical Study on China's Manufacturing Sector
}

\author{
Peixu He ${ }^{1}$, Yana Pei ${ }^{2}$, Chunpei Lin ${ }^{1}$ and Di Ye ${ }^{1, *}$ \\ 1 Business School, Huaqiao University, Quanzhou 362021, China; hepeixu@hqu.edu.cn (P.H.); \\ linchunpei2010@126.com (C.L.) \\ 2 College of Philosophy and Law, Shanghai Normal University, Shanghai 200234, China; peiyana2020@126.com \\ * Correspondence: yedi@hqu.edu.cn
}

Citation: He, P.; Pei, Y.; Lin, C.; Ye, D. Ambidextrous Marketing Capabilities, Exploratory and Exploitative Market-Based Innovation, and Innovation Performance: An Empirical Study on China's Manufacturing Sector. Sustainability 2021, 13, 1146. https://doi.org/10.3390/su13031146

Academic Editor: Erik Hultink

Received: 18 November 2020

Accepted: 16 January 2021

Published: 22 January 2021

Publisher's Note: MDPI stays neutra with regard to jurisdictional claims in published maps and institutional affiliations.

Copyright: (c) 2021 by the authors Licensee MDPI, Basel, Switzerland. This article is an open access article distributed under the terms and conditions of the Creative Commons Attribution (CC BY) license (https:// creativecommons.org/licenses/by/ $4.0 /)$.

\begin{abstract}
Despite the acknowledged importance of innovation for enterprises' sustainable development, in comparison to technological innovation, research on market-based innovation is still in its nascent stage. It is unclear what factors will predict market-based innovation and how market-based innovation boosts innovation performance. Therefore, based on an adaptive marketing capabilities perspective and drawing on insights from the organizational ambidexterity literature, this study explored the relationships among enterprises' marketing capabilities, market-based innovation and innovation performance. Data collected from 237 manufacturing enterprises in China were analyzed using hierarchical regression analysis and bootstrapping methods. The results showed that: (1) Marketing capabilities and market-based innovation activities are both ambidextrous. Specifically, marketing capabilities include marketing exploration capabilities and marketing exploitation capabilities, and market-based innovation includes exploratory market-based innovation and exploitative market-based innovation. (2) Ambidextrous marketing capabilities can enhance innovation performance significantly, with ambidextrous market-based innovation playing a partial mediating role in this relationship. Specifically, marketing exploration capabilities affect innovation performance through the partial mediating role of exploratory market-based innovation, whereas marketing exploitation capabilities affect innovation performance through the partial mediating role of exploitative market-based innovation. (3) Exploratory market-based innovation negatively moderates the relationship between exploitative market-based innovation and innovation performance, and exploitative market-based innovation also exerts a negative moderating effect on the exploratory market-based innovation-innovation performance association. These findings complement and enrich the ambidextrous capability (innovation) theory, helping manufacturing enterprises to better understand and deploy ambidexterity, and hence to achieve sustainability.
\end{abstract}

Keywords: marketing exploration capabilities; marketing exploitation capabilities; balance of ambidextrous capabilities; exploratory market-based innovation; exploitative market-based innovation; innovation performance; sustainable innovation

\section{Introduction}

Innovation performance is vitally important to enterprises' survival and development. Boosting innovation performance has long been a key topic in management theory and practice. Innovation performance refers to the increase in enterprise value due to the use of innovation capabilities, that is, the efficiency of transforming innovation input into results and the economic benefits. It is generally measured by indicators such as enterprise R\&D investment, patent numbers or new products [1,2]. Gimenez-Fernandez et al. [3] described innovation performance as "proportion relative to turnover of new or strongly improved 
products that the company introduced to the market and that were new to the market" (p. 5) or "the share of turnover resulting from new or strongly improved products that the company introduced to the market and that were new to the market during the last three years" (p. 4). It is also understood to mean "the ability to create innovations along the dimensions of products and services, production methods and processes, management or marketing practices" [4].

To summarize the existing research, while most scholars have studied the acquisition of innovation performance from the perspective of products and technologies, they have failed to examine or analyze enterprises' innovation activities and innovation performance outside the context of new product development. However, the majority of enterprises must adopt a dual approach that integrates market development and technology/product innovation. For example, Guo et al.'s [5] in-depth case study has unfolded "the dynamic process by which Huawei utilized dual technology-building and market-seeking strategies to capitalize on those windows of opportunity and to achieve sustained catch-up" (p. 849). Furthermore, as pointed out by Drucker [6], industrial and commercial enterprises possess only two functions, marketing and innovation. Consequently, although product and technology innovations represent a major sources of an enterprise's innovation performance, innovation connected with markets and marketing should not be neglected. In recent years, a number of prominent Chinese enterprises have used marketing methods to enhance end-customer satisfaction and have achieved immense success (e.g., Mi Phone's focus on the enthusiast market), which reveals that the impact of market-level innovation on an enterprise's overall innovation performance is as important as that of product and technology innovation [7]. In other words, innovation performance should go beyond the domain of product and technology innovation and encompass market-based innovation [8], which refers to companies' separation from the current mainstream market, exploring and providing customer values that are different from those of the mainstream market, developing new customer groups or new market segments [7]. In particular, in the era of digital marketing, customers have more media channels to choose from [9], and traditional marketing models affected heavily by Internet-based marketing. In a rapidly changing environment, especially due to COVID-19-induced lockdowns, the enhancement of digital marketing capabilities is becoming more and more important for companies to stay competitive in the global markets [9]. Therefore, Chinese companies urgently need to enhance digital marketing capabilities, implementing new media marketing concepts and new retail models, paying attention to the role of smart and sustainable digital technologies in the transformation of manufacturing product marketing models, and developing a digital marketing strategy.

In accordance with the "capability-activity-performance" theoretical framework [10-12] in the field of strategy and innovation management, enterprises' capabilities include their design and implementation of innovation activities (such as market-based innovation and marketing capabilities) [13]. March [14] proposed the concepts of "exploratory learning" (referring to organizational members breaking through existing norms, standards and practices, and constantly searching, experimenting, and creating new knowledge to improve organizational efficiency. Their behavioral characteristics are searching, adventure, and experimentation, aiming to improve future profits, find new businesses, develop new technologies and new capabilities) and "exploitative learning" (referring to the refining, extension and improvement of existing knowledge by members of the organizations, which promotes continuous small adjustment and improvement in production process, improving and expanding the existing capabilities and technical level of the enterprise, and increasing the income of the existing business). For organizational learning theory, March [6] proposed the concepts of "exploratory" ("experimentation with new alternatives that have returns that are uncertain, distant, and often negative") and "exploitative" ("the refinement and extension of existing competencies, technologies, and paradigms") (p. 85). As known, the perspectives of ambidextrous capabilities (exploratory capabilities and exploitative capabil- 
ities) and ambidextrous innovation (exploratory innovation and exploitative innovation) have gradually won widespread acceptance among scholars [15-23].

Therefore, to bridge marketing and innovation literature and fill the current research gap, we conduct this empirical study. This study investigated the formative mechanism of an enterprise's innovation performance in light of ambidextrous marketing capabilities and ambidextrous market-based innovation. More specifically, based on adaptive marketing capability theory [24], organizational ambidexterity theory [14], and the "capability-activityperformance" theoretical framework [10-12], this study performed empirical testing of the potential impacts of the two critical dynamic and adaptive marketing capabilities of marketing exploration capabilities (reflecting an enterprise's ability to develop new skills, procedures, and marketing capabilities by applying new market-related knowledge) $[25,26]$ and marketing exploitation capabilities (reflecting an enterprise's abilities that "primarily involve improving and refining current skills and procedures associated with existing marketing strategies, including current market segments, positioning, distribution, and other marketing mix strategies") [26] on enterprises' market-based innovation activities and, thus, on the enhancement of their innovation performances. Moreover, this study also attempted to examine the balance hypothesis of an enterprise's ambidextrous marketing capabilities.

The conclusions of this study will provide a valuable source of new knowledge in research on marketing and contain insights that will advance research on ambidextrous marketing capabilities theory. In contrast to previous studies, our research makes the following contributions: First, this study is one of the few studies that explores the sources of corporate innovation performance from the market level, and is the first one that explores the impacts of marketing capabilities and market-based innovation activities on corporate innovation performance in developing markets. We take the lead in detailing and extending the role of marketing capabilities in promoting market-based innovation activities, combining capability factors with innovation models, and at the same time integrating innovation with market factors, linking the innovation management and marketing management together which has been called for further research by scholars. Secondly, existing research still has little knowledge on relationship between marketing resources/capabilities and market innovation activities. Our study has enriched the marketing capabilities and market innovation literature; third, this research further provides implications for the balance of ambidextrous innovative activities at the market level. Meanwhile, the conclusions of this study will provide valuable guidance to managers who seek to rely on marketing capabilities to boost their enterprises' innovation performance.

\section{Theoretical Background and Hypotheses}

\subsection{Ambidextrous Marketing Capabilities and Innovation Performance}

Marketing capability refers to the ability to arrange and use internal and external resources (e.g., knowledge and technology) to meet the market's needs, and thereby realize the goal of profit maximization. Marketing capabilities represent an important means of securing a sustainable competitive advantage and positional advantage for an enterprise [27] and determine whether an enterprise can achieve long-term development in the midst of market competition. Adopting the perspective of Vorhies [28], this study classifies marketing capabilities as marketing exploration capabilities and marketing exploitation capabilities. Here, marketing exploration capabilities refer to the ability to use new market knowledge to develop new skills, processes, and marketing capabilities, while marketing exploitation capabilities refer to an enterprise's ability to achieve valuable results through the enhancement and improvement of existing technologies, processes, and marketing capabilities, and the establishment of greater linkages with existing markets. According to Vorakulpipat and Rezgui [29], ambidextrous marketing capabilities represent an enterprise's different methods of creating and applying knowledge, where the two approaches both assist in the realization of enterprise value. Moreover, Chen et al. [30] suggested that "sustainable competitive advantage of a firm may lie in the firm's ability to exploit its current competencies while simultaneously exploring new capabilities" (p. 198). 
Innovation performance refers to the use of innovation capabilities to drive the enhancement of enterprise value. The realization of innovation performance not only depends on the output of product innovation but also on the output of process innovation, which implies that enterprises must not only develop new products but also optimize innovate processes by using various resources and technologies [31]. Previous research has indicated that (ambidextrous) marketing capabilities can promote the realization of innovation performance. Specifically, Ngo and O'Cass [32] find that a company's functional marketing capabilities are closely related to a company's innovation-related performance. Drechsler et al. [33] argue that knowledge-based marketing capabilities are associated with innovation performance. Zhou et al. [34] point out that exploratory capabilities can positively affect the new product development of multinational enterprises. Huang and $\mathrm{Li}[35]$ reveal that a company's ambidextrous capability is significantly positively correlated with new product performance. Mehrabi et al. [36] explore the relationship between ambidextrous marketing capabilities and corporate performance, including new product development performance. Gok and Peker [37] indicate that marketing capabilities play a vital role in cultivating enterprise innovation performance. They analyzed the role of marketing's innovation-related capabilities in the process of corporate innovation and found that the innovation-related capabilities of the marketing department are significantly positively correlated with the impact of the marketing department on the corporate innovation process. Falasca et al. [38] empirically test the impact of marketing dynamic capability on innovation performance.

Wang and Chen [39] suggested that enterprises can integrate internal and external marketing resources through conducting transformative marketing activities, enabling the creation of new marketing combinations that significantly differ from existing marketing rules, standards, practices, and activities, and thereby gather new opportunities and find new areas of business. Peng et al. [40] indicated that marketing exploration capabilities constitute the foundation for an enterprise's market-based innovation, and an enterprise with strong marketing exploration capabilities can better break out of the status quo and expand into new business areas. Atuahene-Gima [25] included exploration and exploitation among product innovation capabilities and suggested that marketing exploitation capabilities can promote incremental innovation. Day [41] found that an enterprise's development of internal marketing knowledge can assist the enhancement of its innovation performance, and marketing exploitation capabilities can convert knowledge into superior innovation performance. Zhou et al. [34] as well as Huang and Li [35] revealed that the two adaptive capabilities of exploratory and exploitative capability are positively related to enterprises new product development and performance. In addition, Yalcinkaya et al. [42] also found that exploration capabilities positively influence the degree of product innovation and market performance. We consequently proposed the following hypotheses:

Hypothesis 1. Marketing exploration capabilities have a significant positive relationship with innovation performance; i.e., an increase in marketing exploration capabilities leads to an increase in innovation performance.

Hypothesis 2. Marketing exploitation capabilities have a significant positive relationship with innovation performance; i.e., an increase in marketing exploitation capabilities leads to an increase in innovation performance.

\subsection{Ambidextrous Marketing Capabilities and Innovation Performance: The Mediating Role of Ambidextrous Market-Based Innovation}

Day [41] identifies the gap between current market needs and the marketing capabilities of companies to meet these needs, proposing the concept of adaptive marketing capabilities and the evolution path of marketing capabilities, which is about moving from static marketing capabilities to dynamic marketing capabilities and then to adaptive marketing capabilities. According to Day [41], companies need three types of adaptive marketing 
capabilities, which are vigilant market learning, adaptive market experimentation, and open marketing. We believe that marketing exploration and exploitation capabilities provide a foundation for market learning and market experimentation, and thereby promote market-based innovation activities. Therefore, based on the adaptive marketing capabilities perspective, we believe that ambidextrous marketing capabilities have a significant impact on exploratory market-based innovation (emphasizing that companies rely on new market knowledge, using new market knowledge to create and develop new markets that target new customer groups, and request new distribution channel) [7] and exploitative marketbased innovation (emphasizing that companies make full use of their existing market knowledge, continue to explore existing markets while establishing a solid relationship with existing customer groups, identifying new demands that may appear in the existing market) [7] and innovation performance.

2.2.1. Marketing Exploration Capabilities and Innovation Performance: The Mediating Role of Exploratory Market-Based Innovation

Different types of innovation "will likely require different types of capabilities" [43] (p. 1106). Exploratory innovation refers to providing new processes and products and/or create new markets relying on new knowledge or skills [44], and marketing exploration capabilities are well-suited to providing the "raw material" for exploratory innovation. On the one hand, marketing exploration can facilitate the development of novel marketbased resource combinations while enabling the creation of new marketing procedures and providing the organization with new outputs. On the other hand, marketing exploration can also facilitate new allocations and combinations of existing market-based resources and assist an organization in achieving its goals through the application of all-new marketing concepts and methods that depart from the organization's traditional market [40]. Accordingly, marketing exploration capabilities provide a foundation for the development of market-based exploratory innovation and have the chief function of generating new knowledge and new technology, which can give an organization the possibility to engaging in exploratory market-based innovation. Ho et al. [45] point out that marketing exploration emphasizes market experimentation and risk-taking, which can promote enterprises to explore new market segments and propose new solutions to meet the needs of potential customers. In other words, marketing exploration capabilities help promote the market innovation.

The results of exploratory market-based innovation will have a close relationship with an enterprise's innovation performance. Exploratory market learning and innovative methods enable companies to better meet the unique value demands of customer groups from low-end markets or emerging markets [7], promote the formation of differentiated characteristics of new products [46], and achieve the product differentiation [7]. According to Benner and Tushman [47], enterprises can rely on exploratory market-based innovation to obtain advanced knowledge and technology in the fierce competition in markets, and they can employ this knowledge and technology to develop new products and processes, enabling them to occupy an advanced position in emerging markets. Rogan and Mors [48] showed that an enterprise's new product development and new markets occupation will alter the traditional market structure and create new market mechanisms, which will help the enterprise find new directions and create new values for customers. In addition, $\mathrm{He}$ et al. [49] suggested that, on the one hand, exploratory market-based innovation can provide companies with opportunities to perform better than other competitors by exploring transformative solutions in the process of new product development, to better meet customers' needs; on the other hand, it can create a new consumer market and help companies form a new brand image that is different from that of competitors in the mainstream market. Xu et al. [50] took a Chinese local cosmetics brand that is under the transitional economy as an example. They pointed out that innovative forms of exploratory market-based innovation include market expansion, new market entry, and new customer value. When the market environment is turbulent, companies should search for new markets to carry out exploratory market-based innovation, that is, through interaction, 
and cooperative learning, companies are able to obtain complex tacit knowledge about competitors and new markets, to figure out market gaps and achieve exploratory marketbased innovation. All these efforts can lead to healthy development of the brand.

In sum, based on marketing exploration capabilities, firms "design new products or services for marketplaces, create new markets and identify the needs of emerging customers and markets" [51] (p. 735). As such, firms that primarily pursue marketing exploration usually create radical market-based innovation through exploring new marketrelated knowledge. The reason for hypothesizing the mediating role of exploratory marketbased innovation is that marketing exploration capabilities are seen as a type of dynamic capability that can enhance firm performance gradually over time. It is worth noting that, marketing exploration capabilities provide basic elements for achieving market-based innovation benefits; an exploratory market-based innovation mode can further facilitate the transformation of marketing exploration capabilities into feasible marketing activities, which lead to satisfactory market-based innovation performance. Accordingly, this study proposed the following hypotheses:

Hypothesis 3a (H3a). Marketing exploration capabilities have a significant positive relationship with exploratory market-based innovation; i.e., an increase in marketing exploration capabilities leads to an increase in exploratory market-based innovation.

Hypothesis 3b (H3b). Exploratory market-based innovation has a significant positive relationship with innovation performance; i.e., an increase in exploratory market-based innovation leads to an increase in innovation performance.

Hypothesis 3c (H3c). Exploratory market-based innovation mediates the relationship between marketing exploration capabilities and innovation performance.

2.2.2. Marketing Exploitation Capabilities and Innovation Performance: The Mediating Role of Exploitative Market-Based Innovation

$\mathrm{Xu}$ et al. [52] point out that exploitative market-based innovation (that is, relying on the existing market knowledge, or improving the recognition to existing market knowledge, developing the existing market or distribution channels, etc.) can significantly increase existing customer value, while promoting the development of local enterprises. Furthermore, $\mathrm{Xu}$ et al. [50] take a Chinese local cosmetics brand that is under the transitional economy as an example, arguing that the target company has chosen an exploitative market-based innovation strategy to maintain the existing mainstream market. More specifically, this target company has achieved exploitative market-based innovation through knowledge conversion, integrated planning and consistent communication.

On the one hand, exploitative innovation refers to the refinement and improvement of the existing processes and products based on existing knowledge and skills [44], and it emphasizes the development of current markets and the enhancement of current efficiency. In this process, marketing exploitation exerts a significant impact on exploitative innovation. On the other hand, marketing exploitation helps to ultimately create new services and design new market development models. Marketing exploitation is a process to gradually transform the marketing procedures, develop and optimize existing market-related knowledge, re-examine and upgrade marketing procedures [53]. From another angle, marketing exploitation can improve an organization's existing marketing procedures and structures, which will further boost the effectiveness of the organization's innovation activities, and thereby promote incremental innovation [25]. Furthermore, Zhang and Qiu [7] indicated that the improvement of existing products can enable an enterprise to achieve a differentiation-based advantage. Obviously, marketing exploitation not only creates the preconditions for exploitative innovation but can also assist in the improvement of the innovation process, enhance innovation efficiency, and realize a sustainable competitive advantage through differentiation. 
The achievement of superior innovation performance will depend on an enterprise's exploitative market-based innovation. Dong et al. [54] proposed that the effect of exploitative innovation on an enterprise's market-based innovation performance covers two aspects: the first is the optimization of existing knowledge, which enables the needs of existing customers to be satisfied under the enterprise's current conditions and thereby boosts the enterprise's short-term economic effectiveness; the second is the enterprise's utilization of knowledge and skills gained from exploitative market-based innovation to boost the enterprise's operating efficiency and reduce the cost of marketing activities and risk of product innovation, thereby achieving a low-cost competitive advantage, which will help maintain and enhance the enterprise's superior competitiveness, and ultimately enabling it to achieve long-term, stable profits. Kim and Atuahene-Gima [46] found that since exploitative market-based innovation emphasizes market information related to the organization's existing resources, it can effectively reduce the potential costs of new product development. Zhang and Qiu [7] suggested that exploitative market-based innovation can strengthen an enterprise's low-cost competitive advantage and will have a positive effect on an enterprise's overall performance. This reveals that exploitative market-based innovation can reduce the cost of an enterprise's innovation activities, facilitate its market expansion, and enable it to achieve sustainable innovation performance. This study accordingly proposes the following hypotheses:

Hypothesis 4a (H4a). Marketing exploitation capabilities have a significant positive relationship with exploitative market-based innovation; i.e., an increase in marketing exploitation capabilities leads to an increase in exploitative market-based innovation.

Hypothesis $4 \mathbf{b} \mathbf{( H 4 b ) . ~ E x p l o i t a t i v e ~ m a r k e t - b a s e d ~ i n n o v a t i o n ~ h a s ~ a ~ s i g n i f i c a n t ~ p o s i t i v e ~ r e l a t i o n s h i p ~}$ with innovation performance; i.e., an increase in exploitative market-based innovation leads to an increase in innovation performance.

Hypothesis $4 \mathbf{c}(\mathbf{H} 4 \mathbf{c})$. Exploitative market-based innovation mediates the relationship between marketing exploitation capabilities and innovation performance.

2.2.3. The Balance of Ambidextrous Marketing Capabilities: The Mutual Moderating Effect of Marketing Exploration Capabilities and Marketing Exploitation Capabilities

The organizational ambidexterity theory posits that an enterprise that can effectively combine exploratory and exploitative capabilities may be able to achieve a greater competitive advantage than those enterprises that cannot integrate their exploratory and exploitative capabilities [28]. The dynamic capability view also contends that "the dynamic processes of exploitation and exploration are the key sources of an organization's sustainable competitive advantage" [55] (p. 672). Previous empirical studies have further provided evidence of organizational ambidexterity's generally positive impact on performance [56-58]. For example, Cho et al. [59] indicated that balancing exploitation and exploration was significantly and positively associated with startups' performance. Hence, Rothaermel and Deeds [60], Raisch et al. [61], and Zeng et al. [23] called for maintaining an appropriate balance between exploration and exploitation activity for the entirety of a firm's system survival and sustained (long-term) performance. Specifically, enterprises possessing only exploitative capabilities are more likely to encounter performance improvement bottlenecks due to the absence of forward-looking insights and innovative ideas and unwillingness to develop new products, new marketing procedures, and new markets. Conversely, enterprises that possess only exploratory capabilities may face a "failure trap" attributable to the fact that new products and technologies are typically easy to imitate. When exploration is the sole source of an enterprise's competitive advantage, the enterprise will be obligated to undertake costly exploratory activities and will run the risk of being unable to achieve sufficient remuneration [62]. Accordingly, enterprises should employ exploratory activities to create new products and markets while simulta- 
neously relying on exploitative activities to reap the benefit of their new products and markets. Thus, enterprises that wish to maximize their innovation performance must strive to find appropriate equilibria between marketing exploration capabilities and marketing exploitation capabilities and between exploratory market-based innovation and exploitative market-based innovation.

However, recent research has found that exploration and exploitation are competing strategies [26] or separate (though not necessarily antithetical) strategies with different antecedents and performance consequences [63], and thereby are hard to be achieved at the same time [64]. Thus "the strategy targeted for balancing exploitation and exploration should be periodically adjusted, and the limited resources should be allocated during the execution of projects" [30] (p. 198). In particular, marketing exploration and marketing exploitation may have mutual conflicts. For instance, Ho and Lu [16] found that "a negative interaction effect exists between marketing exploitation and marketing exploration on firms' market performance" (p. 1028). According to March [14], a competitive-and not complementary-relationship exists between exploratory activities and exploitative activities, and the two will compete for an organization's limited resources. As a consequence, an organization should develop ambidextrous capabilities and undertake ambidextrous activities only after taking its actual resources into consideration if it hopes to create the greatest possible value [14]. Vorhies et al. [28] suggested that because allocable resources are limited, there will be interactions between the two organizational characteristics, and enhancing advantage with regard to one characteristic will tend to reduce the organization's advantage in the other characteristic. Consequently, an enterprise's marketing exploration and marketing exploitation tend to rise and fall at each other's expense, and those enterprises that attempt to simultaneously maximize marketing exploration and marketing exploitation will lead to a decrease in their customer-focused marketing capabilities. In fact, it is likely that only large enterprises with abundant resources can simultaneously pay full attention to their marketing exploration capabilities and marketing exploitation capabilities, and rely on the integration of these two kinds of capabilities to create greater value, while small and medium-sized enterprises (SMEs) that are relatively lacking in resources should emphasize one type of capability over the other to a certain degree when developing their ambidextrous marketing capabilities [65]. Furthermore, Feng and Xu [66] indicated that the interaction between marketing exploration and marketing exploitation will have a significant negative effect on an enterprise's financial performance and market adaptability. We therefore propose the following hypotheses concerning the mutual moderating effects between marketing exploration capabilities and marketing exploitation capabilities:

Hypothesis 5. Marketing exploration capabilities negatively moderate the positive relationship between marketing exploitation capabilities and exploitative market-based innovation; i.e., the stronger an enterprise's marketing exploration capabilities are, the weaker the linkage between its marketing exploitation capabilities and exploitative market-based innovation.

Hypothesis 6. Marketing exploitation capabilities negatively moderate the positive relationship between marketing exploration capabilities and exploratory market-based innovation; i.e., the stronger an enterprise's marketing exploitation capabilities are, the weaker the linkage between its marketing exploration capabilities and exploratory market-based innovation.

This study preliminarily drafted the conceptual model shown in Figure 1 based on the foregoing theoretical review and hypotheses. 


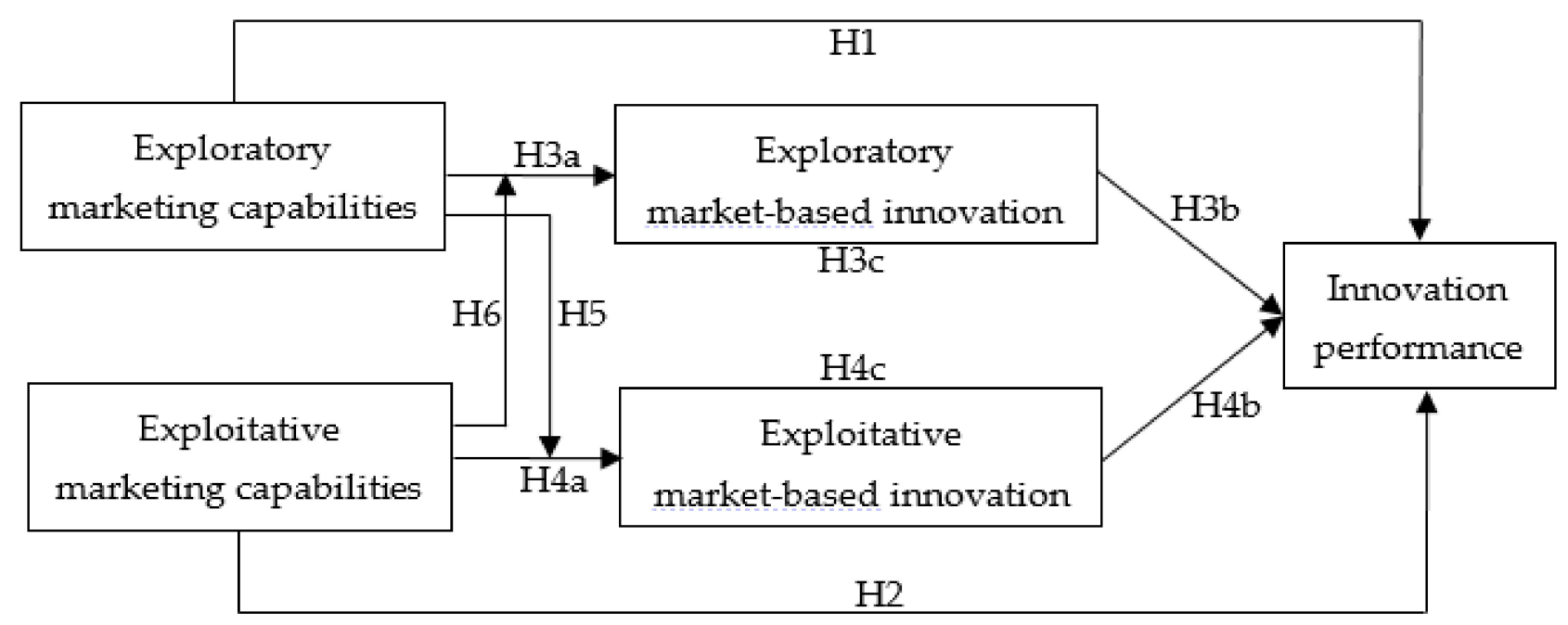

Figure 1. Conceptual model.

\section{Methods}

\subsection{Participants and Procedure}

Data were collected from both high-tech and non-high-tech manufacturing enterprises in China's Fujian province. With the assistance of the management committees of ten industrial parks in Quanzhou, Xiamen, Fuzhou, Zhangzhou, and Putian in Fujian province, we randomly selected 300 manufacturing enterprises to conduct our survey. The participants were senior presidents and top managers who engaged in new product development and marketing activities, and were familiar with the enterprise's overall strategies. When the participants had a poor grasp of certain content, we asked that the managers of relevant functional departments assist in filling out the questionnaire. In order to reduce the social desirability bias of the study, on the front page of the questionnaire, we informed the participants of the purpose of the survey, the voluntary nature of participation, an assurance of anonymity and confidentiality, and the contact information of the corresponding author. Following Richman et al. [67] participants were requested to complete the questionnaires alone during working hours and return them to the corresponding author in sealed envelopes. Translation and back-translation procedure [68] was adopted to verify the questionnaire in Chinese. The survey was conducted in July and August, 2018. The researchers distributed a total of 300 questionnaires, collected 284 completed questionnaires, and obtained a total of 237 valid questionnaires after deleting 47 invalid questionnaires, representing an overall response rate of $79 \%$. Table 1 shows the results of the descriptive statistical analysis of valid samples. The enterprises comprising the sample spanned an extremely broad range of industry areas and had a normal distribution in terms of various indicators (i.e., the enterprise's age, size, nature of ownership, and industry type), which indicates a good representativeness. 
Table 1. Descriptive statistical analysis $(N=237)$.

\begin{tabular}{|c|c|c|c|c|c|}
\hline \multicolumn{2}{|c|}{ Variables } & Sample Characteristic & Freq. & $\%$ & Cumulative $\%$ \\
\hline \multirow{4}{*}{\multicolumn{2}{|c|}{$\begin{array}{c}\text { Age } \\
\text { (years since establishment) }\end{array}$}} & Less than 3 years & 28 & 11.81 & 11.81 \\
\hline & & $3-5$ years & 37 & 15.61 & 27.42 \\
\hline & & $5-10$ years & 77 & 32.49 & 59.91 \\
\hline & & Over 10 years & 95 & 40.08 & 100 \\
\hline \multirow{4}{*}{\multicolumn{2}{|c|}{$\begin{array}{c}\text { Size } \\
\text { (number of employees) }\end{array}$}} & Less than 100 employees & 51 & 21.52 & 21.52 \\
\hline & & 100-500 employees & 61 & 25.74 & 47.26 \\
\hline & & 500-1000 employees & 86 & 36.29 & 83.55 \\
\hline & & Over 1000 employees & 39 & 16.46 & 100 \\
\hline \multirow{4}{*}{\multicolumn{2}{|c|}{ Nature of ownership }} & State-owned & 37 & 15.61 & 15.61 \\
\hline & & Private & 115 & 48.52 & 64.14 \\
\hline & & Foreign capital & 29 & 12.24 & 76.37 \\
\hline & & Other type & 56 & 23.63 & 100 \\
\hline \multirow{20}{*}{ Industry type } & \multirow{10}{*}{$\begin{array}{l}\text { High-tech } \\
\text { manufacturing }\end{array}$} & Cloud computing and software & 10 & 4.22 & \multirow{10}{*}{40.51} \\
\hline & & Microelectronics technology & 4 & 1.69 & \\
\hline & & Specialized video application service platform technology & 2 & 0.84 & \\
\hline & & New electronic elements & 13 & 5.49 & \\
\hline & & Smart transportation and rail transportation technology & 4 & 1.69 & \\
\hline & & Biotech and new pharmaceuticals & 6 & 2.53 & \\
\hline & & Medical instruments and devices & 3 & 1.27 & \\
\hline & & New materials & 21 & 8.86 & \\
\hline & & New energy and energy conservation & 9 & 3.80 & \\
\hline & & Advanced manufacturing and automation & 24 & 10.13 & \\
\hline & \multirow{10}{*}{$\begin{array}{l}\text { Non-high-tech } \\
\text { manufacturing }\end{array}$} & Textiles & 36 & 15.19 & \multirow{10}{*}{59.49} \\
\hline & & Clothing & 22 & 9.28 & \\
\hline & & Leather & 16 & 6.75 & \\
\hline & & Chemical engineering & 9 & 3.80 & \\
\hline & & Synthetic fibers & 3 & 1.27 & \\
\hline & & Papermaking & 2 & 0.84 & \\
\hline & & Rubber and plastics & 11 & 4.64 & \\
\hline & & Building materials & 15 & 6.33 & \\
\hline & & Nonferrous metal processing & 8 & 3.38 & \\
\hline & & Agricultural and sideline food processing & 19 & 8.02 & \\
\hline
\end{tabular}

High-tech manufacturing firms and non-high-tech manufacturing firms have huge differences in their products and market environment, and their dependence on technology and the market is not the same. Therefore, managers of these two types of enterprises may also have different preferences in terms of "exploration" and "utilization/development". Generally speaking, high-tech manufacturing firms that master core technologies face less pressure from external competition, while traditional manufacturing firms that lack core competitive advantages are facing greater pressures to survive due to strong competition under the Chinese transitional economy. Therefore, both types of companies may invest differently in technological innovation and market innovation. More specifically, in terms of market-based innovation, high-tech manufacturing firms advocate exploring and providing new value propositions that are different from those of traditional markets. They target new market segments, launching differentiated and customized products, and attracting new customers. Due to their relatively good reserves of technical resources, these companies have a strong willingness to develop new products and seek product differentiation advantages. They continue to pay attention to the features and functions of leading products with top technical standards, and tend to implement breakthrough innovative product strategies and exploratory market-based innovation strategies in emerging markets. Considering the non-high-tech manufacturing firms that tend to rely on lowcost advantages to increase market attractiveness, they implement incremental product innovation strategies for mature markets, and adopt exploitative market-based innovation models to reduce the cost of market-based innovation and operation. Obviously, both types 
of companies may show differences in their strategic focus and investment in traditional markets and emerging markets, exploratory/exploitative marketing capabilities, and exploratory/exploitative market-based innovation. Therefore, this study considers industry type as one of the potential influencing factors.

\subsection{Measures}

To ensure the reliability and validity of the measurement scale, this study adopted the scales that had been widely-used in previous literature. We also modified some items to fit the Chinese cultural context. All variables except for control variables (i.e., the basic information of the enterprises) were measured using a 7-point Liker scale, ranging from $1=$ strongly disagree to 7 = strongly agree.

Marketing exploration capabilities and marketing exploitation capabilities were measured using Vorhies et al.'s [28] 8-item scale. The marketing exploration capabilities scale intends to measure an enterprise's ability to develop new skills, procedures, and marketing capabilities by applying new market-related knowledge $[25,26]$. The scale consists of the following four items: "Continually developing new marketing procedures that are very different from others developed in the past" (MERC1), "Routinely introducing new marketing procedures which are daring, risky, or bold" (MERC2), "Consistently using market knowledge to develop new marketing processes which deliver different outputs from existing processes" (MERC3), and "Using marketing knowledge to "break the mold" and create new marketing processes not used before" (MERC4). The Cronbach's $\alpha$ was 0.83 in this study. The marketing exploitation capabilities scale intends to measure an enterprise's ability that "primarily involve improving and refining current skills and procedures associated with existing marketing strategies, including current market segments, positioning, distribution, and other marketing mix strategies" (p. 221) [26]. The scale consists of the following four items: "Consistently reexamining information from previous projects and/or studies to modify existing marketing processes" (METC1), "Routinely adapting existing ideas when developing new marketing processes" (METC2), "Incrementally and routinely improving our existing marketing procedures" (METC3), and "Focusing changes in marketing procedures on improving efficiency" (METC4). The Cronbach's $\alpha$ was 0.90 in this study.

We used the eight-item scale modified and developed by Zhang and Qiu [7] based on existing measures of market-based innovation [58,69] to measure exploratory and exploitative market-based innovation. By adopting the exploratory market-based innovation scale, we intended to measure an enterprise's activities relating to use marketing knowledge to create and develop new markets that do not involve existing customer groups and to develop new marketing channels [7]. The scale consists of the following four items: "My company has consistently taken active steps to develop new markets" (ERMI1), "My company is constantly searching for information on customer groups with different needs and behavioral models" (ERMI2), "My company strives to establish connections with diverse customer groups" (ERMI3), and "My company is constantly searching for and establishing diverse marketing channels" (ERMI4). The Cronbach's $\alpha$ for this scale was 0.88. We employed the exploitative market-based innovation scale to assess the degree to which an enterprise mines existing market knowledge, continues to develop existing markets, establishes durable relationships with existing customer groups, and simultaneously uncovers new needs that may have appeared in existing markets [7]. The scale consists of the following four items: "My company strives to develop its existing markets" (ETMI1), "My company is constantly uncovering new needs and characteristics of the customers in existing markets" (ETMI2), "My company strives to provide even more services to existing customers" (ETMI3), and "My company strives to establish durable relationships with existing customers" (ETMI4). The Cronbach's $\alpha$ for this scale was 0.89 .

While numerous scholars have used the number of patents as a major assessment indicator in previous research, more recent studies have pointed out that merely using the number of patents to measure an enterprise's innovation performance will encounter great 
limitations [70]. This study consequently employed the following 5 items to measure innovation performance by referring to Bell [71], Ritter and Gemünden [72], and Qian et al. [70]: "Compared with competitors, my company has made a large number of patent applications" (IP1), "Compared with competitors, my company commonly takes the lead in our industry in introducing new products/services" (IP2), "Compared with competitors, my company's product improvements and innovations have elicited excellent responses from the market" (IP3), "Compared with competitors, my company's new product development efforts have had an extremely high success rate" (IP4), and "Compared with competitors, my company can occupy new markets with even greater speed" (IP5). The Cronbach's $\alpha$ for this scale was 0.93 .

In accordance with previous research, we controlled for the enterprises' age, size, nature of ownership, and industry type in the data analyses. Specifically, age (years since establishment) and size (number of employees) were coded as continuous variables, and nature of ownership (state-owned, private, foreign capital, and other type) and industry type (non-high-tech manufacturing and high-tech manufacturing) were coded as a dummy variable.

\section{Data Analysis and Hypothesis Testing}

\subsection{Confirmatory Factor Analysis}

We employed AMOS 17.0 to test the discriminant validity of the study variables. We used $\chi^{2}(d f)$, RMSEA, CFI, and TLI as indicators to assess the goodness of fit of our hypothesized five-factor model and several alternative measurement models. In accordance with the recommendation of Bentler and Bonett [73], a good model fit is verified when $1<\chi^{2} / d f<3$, RMSEA $<0.08$, CFI $>0.90$, and TLI $>0.90$. Table 2 showed that our hypothesized five-factor model yielded a better goodness of fit than other alternative models, which indicated that the study variables had a good discriminant validity.

Table 2. Results of confirmatory factor analysis of the measurement models $(N=237)$.

\begin{tabular}{|c|c|c|c|c|c|}
\hline Measurement Models & $\chi^{2}(d f)$ & $\Delta \chi^{2}(\Delta d f)$ & $C F I$ & $T L I$ & RMSEA \\
\hline $\begin{array}{c}\text { Five-factor model } \\
\text { (MERC; METC; ERMI; ETMI; IP) }\end{array}$ & $877.60(179)^{* *}$ & & 0.92 & 0.93 & 0.06 \\
\hline $\begin{array}{c}\text { Four-factor model } \\
(\text { MERC+METC; ERMI; ETMI; IP) }\end{array}$ & $1169.49(183)^{* *}$ & $291.89(4)^{* *}$ & 0.85 & 0.83 & 0.09 \\
\hline $\begin{array}{c}\text { Four-factor model } \\
\text { (MERC; METC; ERMI+ETMI; IP) }\end{array}$ & $1090.76(183)^{* *}$ & $213.16(4)^{* *}$ & 0.84 & 0.84 & 0.09 \\
\hline $\begin{array}{c}\text { Three-factor model } \\
\text { (MERC+METC; ERMI+ETMI; IP) }\end{array}$ & $1260.10(186)^{* *}$ & $382.50(7)^{* *}$ & 0.75 & 0.77 & 0.12 \\
\hline $\begin{array}{c}\text { One-factor model } \\
(\text { MERC+METC+ERMI+ETMI+IP) }\end{array}$ & $2535.15(189)^{* *}$ & $1657.55(10)^{* *}$ & 0.49 & 0.46 & 0.16 \\
\hline
\end{tabular}

Note: ${ }^{* *} p<0.01$. Chi-square change $\left(\Delta \chi^{2}\right)$ and degree-of-freedom change $(\Delta d f)$ were against the five-factor model. RMSEA, root mean square error of approximation; CFI, comparative fit index; TLI, Tucker-Lewis index; MERC, marketing exploration capabilities; METC, marketing exploitation capabilities; ERMI, exploratory market-based innovation; ETMI, exploitative market-based innovation; IP, innovation performance.

\subsection{Variable Descriptive Statistics and Correlation Analysis}

Table 3 presents the means, standard deviations and correlations among the study variables. As shown in Table 3, the means of the variables were all relatively high, and there were significant positive correlations between ambidextrous marketing capabilities and innovation performance, between ambidextrous market-based innovation and innovation performance, and between ambidextrous marketing capabilities and ambidextrous marketbased innovation. This provided a basis for the testing of our hypotheses. In addition, this study used hierarchical multiple regression and bootstrapping as more precise tests of the relationships among the variables. 
Table 3. Means, standard deviations, and correlations for the study variables $(N=237)$.

\begin{tabular}{ccccccccccc}
\hline Variables & Mean & $S D$ & $\mathbf{1}$ & $\mathbf{2}$ & $\mathbf{3}$ & $\mathbf{4}$ & $\mathbf{5}$ & $\mathbf{6}$ & $\mathbf{7}$ & $\mathbf{8}$ \\
\hline 1. Age & 13.26 & 9.38 & & & & & & & \\
2. Size & 394.60 & 725.90 & $0.18^{* *}$ & & & & & & \\
3. Nature of ownership & 2.44 & 1.02 & -0.11 & $-0.24^{* *}$ & & & & & \\
4. Industry type & 1.32 & 0.47 & -0.05 & $-0.20^{* *}$ & $0.14^{*}$ & & & & \\
5. MERC & 5.02 & 1.04 & $-0.13^{*}$ & 0.03 & $0.14^{*}$ & 0.06 & & & \\
6. METC & 5.19 & 1.61 & 0.03 & 0.11 & 0.06 & $-0.16^{*}$ & $0.33^{* *}$ & & \\
7. ERMI & 4.60 & 1.27 & -0.06 & 0.06 & $0.14^{*}$ & 0.04 & $0.62^{* *}$ & $0.30^{* *}$ & \\
8. ETMI & 4.88 & 1.15 & $-0.19^{* *}$ & -0.05 & 0.13 & 0.05 & $0.19^{*}$ & $0.68^{* *}$ & $0.41^{* *}$ \\
9. IP & 4.94 & 1.07 & 0.03 & -0.01 & 0.07 & -0.06 & $0.56^{* *}$ & $0.71^{* *}$ & $0.51^{* *}$ & $0.59 *$ \\
\hline
\end{tabular}

Note: ${ }^{* *} p<0.01,{ }^{*} p<0.05$. MERC, marketing exploration capabilities; METC, marketing exploitation capabilities; ERMI, exploratory market-based innovation; ETMI, exploitative market-based innovation; IP, innovation performance.

\subsection{Hypothesis Testing}

Hypothesis 1 and Hypothesis 2 proposed that a manufacturing enterprise's marketing exploration capabilities and marketing exploitation capabilities both have significant positive correlations with the enterprise's innovation performance. We employed hierarchical multiple regression analysis to test our hypotheses (see Table 4). As shown by Model 1 and Model 2 in Table 4, after controlling for the enterprises' age, size, nature of ownership, and industry type, strong positive correlations existed between innovation performance and both marketing exploration capabilities and marketing exploitation capabilities ( $\beta$ values of 0.603 and 0.485 , respectively, $p<0.010$ ). Accordingly, Hypothesis 1 and Hypothesis 2 were supported.

Table 4. Results of hierarchical regression analyses $(N=237)$.

\begin{tabular}{|c|c|c|c|c|c|c|c|c|c|c|}
\hline \multirow{2}{*}{ Variables } & \multicolumn{6}{|c|}{ IP } & \multicolumn{2}{|c|}{ ERMI } & \multicolumn{2}{|c|}{ ETMI } \\
\hline & Model 1 & Model 2 & Model 3 & Model 4 & Model 5 & Model 6 & Model 7 & Model 8 & Model 9 & Model 10 \\
\hline \multicolumn{11}{|l|}{ Control Variable } \\
\hline Age & 0.006 & 0.002 & 0.004 & 0.010 & 0.007 & 0.008 & -0.001 & -0.003 & -0.013 & -0.010 \\
\hline Size & -0.000 & 0.000 & -0.000 & 0.000 & 0.000 & 0.000 & 0.000 & 0.000 & 0.000 & -0.000 \\
\hline $\begin{array}{l}\text { Nature of } \\
\text { ownership }\end{array}$ & 0.017 & 0.030 & 0.012 & 0.027 & 0.076 & 0.014 & 0.065 & 0.106 * & 0.036 & 0.061 \\
\hline $\begin{array}{l}\text { Industry type } \\
\text { Independent } \\
\text { Variable }\end{array}$ & $-0.304 *$ & -0.078 & -0.199 & -0.134 & $-0.277^{*}$ & -0.055 & -0.163 & $-0.134 *$ & -0.050 & $-0.195 *$ \\
\hline MERC & $0.603 * *$ & & & & $0.431 * *$ & & $0.525 * *$ & & & \\
\hline METC & & $0.485 * *$ & & & & $0.309 * *$ & & & $0.386 * *$ & \\
\hline \multicolumn{11}{|l|}{ Mediator } \\
\hline ERMI & & & $0.554^{* *}$ & & $0.328^{* *}$ & & & & & \\
\hline ETMI & & & & $0.683 * *$ & & $0.456^{* *}$ & & & & \\
\hline Moderator: MERC & & & & & & & & & & 0.007 \\
\hline $\begin{array}{c}\text { Interaction: } \\
\text { METC*MERC }\end{array}$ & & & & & & & & & & $-0.253^{* *}$ \\
\hline Moderator: METC & & & & & & & & 0.014 & & \\
\hline $\begin{array}{c}\text { Interaction: } \\
\text { MERC*METC }\end{array}$ & & & & & & & & $-0.297^{* *}$ & & \\
\hline$R^{2}$ & 0.243 & 0.218 & 0.209 & 0.227 & 0.290 & 0.283 & 0.306 & 0.217 & 0.333 & 0.312 \\
\hline$F$ & $14.860^{* *}$ & $12.909 * *$ & $12.228^{* *}$ & $13.541^{* *}$ & $15.672 * *$ & $15.133^{* *}$ & $20.338^{* *}$ & $12.788^{* *}$ & $23.074^{* *}$ & $17.417^{* *}$ \\
\hline$\Delta R^{2}$ & 0.227 & 0.201 & 0.192 & 0.210 & 0.272 & 0.264 & 0.291 & 0.197 & 0.319 & 0.294 \\
\hline$\Delta F$ & $66.795^{* *}$ & $57.279 * *$ & $53.957 * *$ & $60.363^{* *}$ & $43.033 * *$ & $41.455^{* *}$ & $87.928^{* *}$ & $51.741^{* *}$ & $91.265^{* *}$ & $77.564 * *$ \\
\hline
\end{tabular}

Note: ${ }^{* *} p<0.01,{ }^{*} p<0.05$. MERC, marketing exploration capabilities; METC, marketing exploitation capabilities; ERMI, exploratory market-based innovation; ETMI, exploitative market-based innovation; IP, innovation performance.

Hypothesis 3 proposed that exploratory market-based innovation has a mediating effect on the relationship between marketing exploration capabilities and innovation performance; Hypothesis 4 proposed that exploitative market-based innovation has a mediating effect on the relationship between marketing exploitation capabilities and innovation performance. This study adopted the standard procedures (generally, it contains four- 
step hierarchical multiple regressions) recommended by Baron and Kenny [74] to test the significance of mediating effects. We considered the hypothesized mediating model (X (marketing exploration capabilities/marketing exploitation capabilities) $\rightarrow \mathrm{M}$ (exploratory market-based innovation/exploitative market-based innovation) $\rightarrow Y$ (innovation performance)) supported if (1) X significantly impacts $Y$, (2) X significantly impacts $M$, (3) M significantly impacts $Y$, and (4) M significantly impacts $Y$ while controlling for $X$, whereas the impact of $X$ on $Y$ is significantly reduced (partial mediation effect) or no longer significant (full mediation effect).

Because Hypothesis 1 and Hypothesis 2 have both already been verified, condition (1) was satisfied. Model 7 and Model 9 in Table 4 revealed that significant positive correlations exist between marketing exploration capabilities and exploratory market-based innovation $(\beta=0.525, p<0.01)$ and between marketing exploitation capabilities and exploitative market-based innovation $(\beta=0.386, p<0.01)$, which indicated that condition (2) was satisfied. Model 3 and Model 4 in Table 4 showed that both exploratory market-based innovation $(\beta=0.554, p<0.01)$ and exploitative market-based innovation $(\beta=0.683, p<0.01)$ have significant correlations with innovation performance, which indicated that condition (3) was satisfied. Model 5 in Table 4 showed that exploratory market-based innovation significantly impacts innovation performance $(\beta=0.328, p<0.01)$ while controlling for marketing exploration capabilities, whereas the impact of marketing exploration capabilities on innovation performance is still significant $(\beta=0.431, p<0.01)$, but the correlation is weaker ( $\beta$ coefficient falls from 0.603 to 0.431 ). Thus, exploratory market-based innovation has a partial mediating effect on the relationship between marketing exploration capabilities and innovation performance, and thereby Hypotheses $3 a, 3 b$, and $3 c$ were verified. Similarly, Model 6 in Table 4 showed that exploitative market-based innovation significantly impacts innovation performance $(\beta=0.456, p<0.01)$ while controlling for marketing exploitation capabilities, whereas the impact of marketing exploitation capabilities on innovation performance is still significant $(\beta=0.309, p<0.01)$, but the correlation is weaker ( $\beta$ coefficient falls from 0.485 to 0.309 ). These findings indicated that exploitative market-based innovation exerts a partial mediating effect on the relationship between marketing exploitation capabilities and innovation performance, and hence Hypotheses $4 a, b$, and c were also verified.

Furthermore, Hypothesis 5 proposed that marketing exploration capabilities significantly moderates the relationship between marketing exploitation capabilities and exploitative market-based innovation, while Hypothesis 6 proposed that marketing exploitation capabilities significantly moderated the relationship between marketing exploration capabilities and exploratory market-based innovation. Model 10 in Table 4 showed that the interaction term involving marketing exploitation capabilities and marketing exploration capabilities has a significant negative effect on exploitative market-based innovation $(\beta=-0.253, p<0.010)$. This finding indicated that marketing exploration capabilities significantly and negatively moderates the influence of marketing exploitation capabilities on exploitative market innovation. Therefore, Hypothesis 5 was supported. Model 8 in Table 4 showed that the interaction term involving marketing exploration capabilities and marketing exploitation capabilities has a significant negative effect on exploratory market-based innovation $(\beta=-0.297, p<0.010)$, which indicated that marketing exploitation capabilities has a significant negative moderating effect on the influence of marketing exploration capabilities on exploratory market-based innovation. Therefore, Hypothesis 6 was also supported.

We then plotted the interaction effects at different levels (i.e., one standard deviation above or below the mean level) of marketing exploration capabilities/marketing exploitation capabilities following the recommendation of Aiken and West [75]. Figure 2 showed that the interaction patterns are as expected in that the marketing exploitation capabilitiesexploitative market-based innovation association is relatively weaker for high rather than low marketing exploration capabilities. Figure 3 showed that the interaction patterns are as expected in that the marketing exploration capabilities-exploratory market-based 
innovation association is relatively weaker for high rather than low marketing exploitation capabilities. These findings lend further support to Hypothesis 5 and Hypothesis 6.

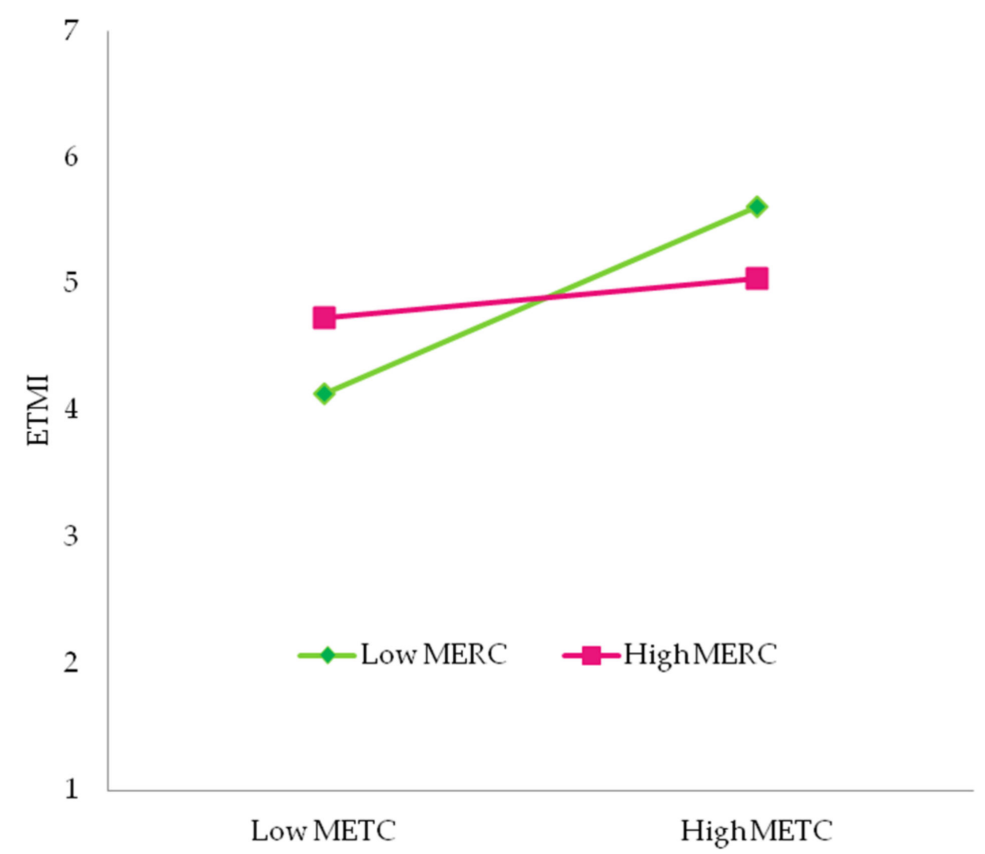

Figure 2. Interaction of METC and MERC on ETMI.

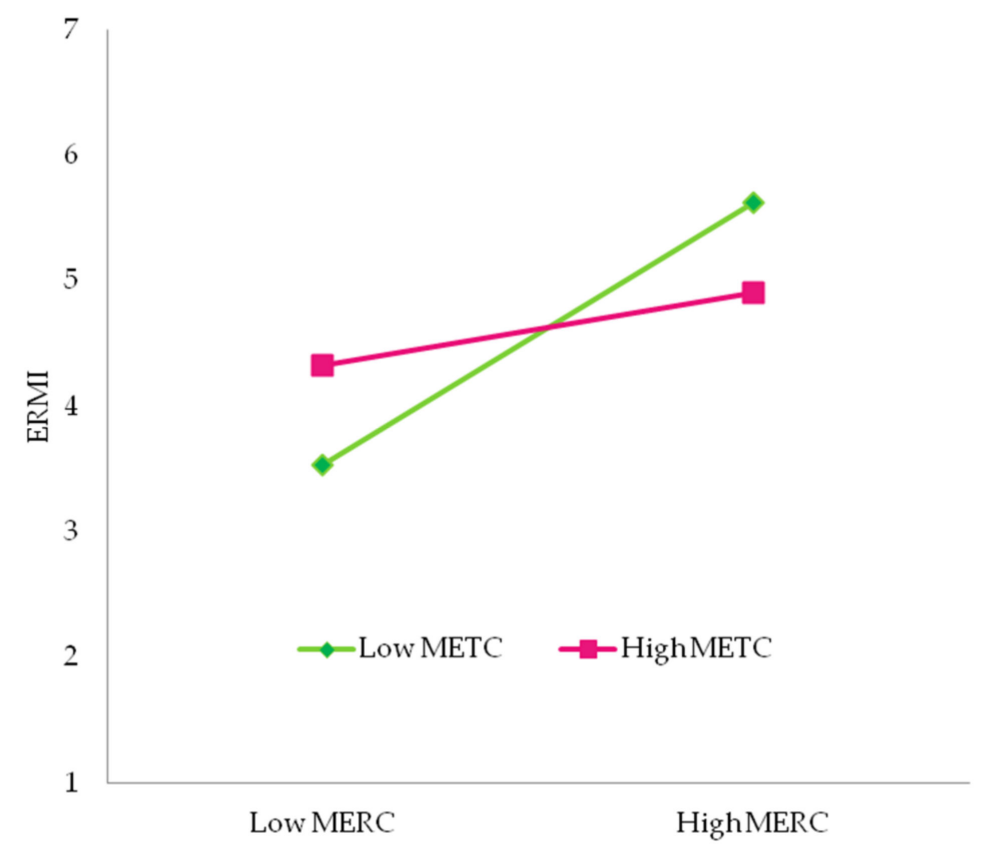

Figure 3. Interaction of MERC and METC on ERMI.

\section{Conclusions and Discussion}

\subsection{Conclusions}

First, the present study verified that ambidextrous marketing capabilities can significantly enhance a manufacturing enterprise's innovation performance. The "capabilityactivity-performance" theoretical framework [10-12] suggests that the enhancement of an enterprise's dynamic capabilities is a key mechanism for driving the achievement of superior performance. While most previous research focused on the effects of new product and technology development capabilities in promoting innovation performance, 
and overlooked the importance of integrating marketing knowledge and capabilities, the results of this study indicated that marketing exploration capabilities and marketing exploitation capabilities both promote the establishment of adaptive marketing capabilities, enabling enterprises to adapt dynamically to changes in the external market environment. The integration of ambidextrous marketing capabilities is another important source of a manufacturing enterprise's innovation performance. Although it is difficult to combine exploration and exploitation, enterprises must engage in both marketing exploration and marketing exploitation.

Second, this study revealed that ambidextrous marketing capabilities can influence innovation performance via ambidextrous market-based innovation activities. Specifically, marketing exploration capabilities and marketing exploitation capabilities, respectively, influence exploratory market-based innovation and exploitative market-based innovation activities. This result indicates that the enhancement of the innovation performance of manufacturing enterprises depends on the adoption of diversified market-based innovation activities, which will further rely on the establishment of varied marketing capabilities.

Third, the current study also found that a high level of marketing exploration capabilities will weaken the relationship between marketing exploitation capabilities and exploitative market-based innovation, and a high level of marketing exploitation capabilities will also weaken the relationship between marketing exploration capabilities and exploratory market-based innovation. This may imply that, for manufacturing enterprises, ambidextrous marketing capabilities tend to rise and fall at each other's expense. In other words, in the case of Chinese manufacturing enterprises, the cultivation of marketing exploration capabilities (or marketing exploitation capabilities) will tend to eat into the key organizational resources needed for the development of marketing exploitation capabilities (or marketing exploration capabilities). Therefore, although ambidexterity "is usually cited as a mean to achieve above average sustainable performance" [76] (p. 181), Chinese manufacturing enterprises must not blindly pursue "combined ambidexterity" (achieving high levels of exploration and exploitation simultaneously) [64,77] or "balanced ambidexterity" (achieving equal levels of exploration and exploitation) [14]. Moreover, our findings also suggest that manufacturing enterprises should exercise a certain degree of preference when selecting and cultivating their key marketing capabilities, and their preferences should reflect their market-based innovation goals (exploratory/radical innovation or exploitative/incremental innovation).

\subsection{Theoretical Contributions}

The findings of this study have important implications for the developing of marketing and innovation theory. On the one hand, this study verified the significant promoting effects of ambidextrous marketing capabilities on innovation performance and clarified the influencing mechanism (i.e., the pathway) between the two. Apart from direct influence, ambidextrous marketing capabilities can also boost a manufacturing enterprise's innovation performance via ambidextrous market-based innovation activities. Furthermore, the mechanism by which marketing exploration capabilities and marketing exploitation capabilities influence market-based innovation can be thought of as being completely separate, with the former chiefly promoting an enterprise's exploratory market-based innovation and the latter chiefly promoting the enterprise's exploitative market-based innovation. Despite the vital influence of strategic marketing ambidexterity ("the blend of a firm's exploitation of existing competencies and exploration of future capabilities in strategic marketing activities", p. 539) [78] on firm performance, research on ambidextrous marketing capabilities is limited [36]. The limited research almost exclusively investigated marketing exploration and marketing exploitation in the product innovation context $[25,69]$. In a quite different way, this study incorporated market-based innovation-which is an easily overlooked aspect-in research on enterprises' ambidextrous marketing capabilities and thus was able to achieve a broader perspective of organizational marketing capabilities. 
On the other hand, this study suggested that marketing exploration capabilities and marketing exploitation capabilities have a mutually constraining relationship to a certain degree, which indicates that manufacturing enterprises are unable to simultaneously maximize these two marketing capabilities with different characteristics. Accordingly, the results of this study provide empirical support for the supposition from a resourcebased theory [79-81] perspective that an organization's ambidextrous capabilities and ambidextrous innovation cannot be simultaneously maximized. In this way, the present study has promoted the development of organizational ambidexterity theory in China. It has also shed a new light on the innovation performance research stream and provided some new directions for future research on the relationship between an organization's ambidextrous capabilities and the relationship between an organization's ambidextrous innovation activities.

\subsection{Managerial Implications}

This study provides significant insights into the management of manufacturing enterprises in China. First, marketing capabilities and market-based innovation activities have great influence on manufacturing enterprises' innovation performance. Thus, manufacturing enterprises should place greater emphasis on the enhancement of customer-focused adaptive marketing capabilities and seek to realize the coordinated development of marketing capabilities and technological capabilities, and market-based innovation and product innovation. Second, it may be counterproductive for manufacturing enterprises to excessively pursue marketing exploration capabilities and marketing exploitation capabilities simultaneously. Resource allocation perspective has been proposed as the central idea to handle the trade-off between exploration and exploitation [82,83]. Heirati et al. [84] have called for identifying the resource conditions that maximize the ambidexterity-new product performance relationship. Therefore, manufacturing enterprises should approach the maximization of ambidextrous capabilities with a cautious attitude, take their actual resources into full consideration, and ensure that the investment of resources in the development of marketing exploration capabilities and marketing exploitation capabilities be maintained at a reasonable level. Because inflection points may be reached in the enhancement of marketing exploration capabilities and marketing exploitation capabilities, manufacturing enterprises should seek to find an equilibrium between the two, reflecting the current state of the enterprise's resources. In view that "exploitation and exploration strategies are associated with different organizational structures" [85] (p. 96) and "exploitative innovation was more important than exploratory innovation for startup restaurants, while exploratory innovation was more important for established restaurants" [59] (p. 1), an enterprise may preferentially develop different marketing capabilities (exploratory or exploitative marketing capabilities) in view of its market environment, organizational structure, and corporate life cycle and attempt to achieve different market-based innovation goals (exploratory or exploitative market-based innovation).

\subsection{Limitations and Future Research}

There are still some limitations and several avenues for future research that need to be addressed. Specifically, first, due to time, energy and resource constraints, we only collected data from a single province in China, which may limit the generalizability of the research conclusions to a certain extent. Future research could apply our research framework in more regions and countries to examine the generalizability of the research conclusions; second, our data were collected from manufacturing enterprises. It is worth noting that manufacturing companies and service companies may have very different focus on marketing capabilities and market-based innovation. Therefore, in the future, researchers can further collect sample data from companies in different industries, conducting comparative studies, and expanding our research conclusions; third, this study uses the self-reporting method to collect data. This self-perception measurement method tends to be overestimated; fourth, this study did not explore the plausible contextual variables that 
play moderating roles in the exploratory (exploitative) marketing capabilities-innovation performance relation. Previous research has investigated the influence of national culture on exploratory and exploitative innovation [86] and the fit between an organization's culture and its innovation strategy [87], and called for more research on the contextual factors (e.g., culture, values, and vision) that facilitate ambidexterity [88,89]. In particular, Wei et al. [21] indicated that the effects of ambidexterity on firm performance are contingent on the firm's strategic orientation. Therefore, to paint a more comprehensive and coherent picture of when ambidextrous marketing capabilities influence innovation performance, future scholars are encouraged to consider strategic orientation (e.g., proactive or responsive market orientations) as potential moderators of this mediated model. In addition, another important step that warrants future research attention might be testing the effect the interaction of exploitation and exploration on firm performance by considering the contingent role of market turbulence or strategic orientation. By doing so, future research is expected to enrich the contextual organizational ambidexterity literature and also contribute to the debate regarding the complementary or incompatible relationship between exploitation and exploration.

Author Contributions: P.H., Y.P. and C.L. conceived and designed the experiments; P.H. and D.Y. performed the experiments; P.H. and Y.P. analyzed the data; C.L. contributed reagents/materials/analysis tools; P.H., Y.P. and D.Y. wrote the paper. All authors have read and agreed to the published version of the manuscript.

Funding: This research was funded by [Huaqiao University's Academic Project supported by the Fundamental Research Funds for the Central Universities] grant number [18SKGC-QT01].

Institutional Review Board Statement: Not applicable.

Informed Consent Statement: Not applicable.

Data Availability Statement: The data presented in this study are available on request from the corresponding author.

Acknowledgments: This study was supported financially by the Huaqiao University's Academic Project supported by the Fundamental Research Funds for the Central Universities (18SKGC-QT01).

Conflicts of Interest: The authors declare no conflict of interest.

\section{References}

1. Jiang, B.B.; Kuang, H.B. Measurement of of firms' innovative performance based on "efficiency-output": Literature review and conceptual framework. Sci. Res. Manag. 2015, 36, 71-78.

2. Xie, X.; Wang, H. The impact mechanism of network embeddedness on firm innovation performance: A moderated mediation model based on non-R\&D innovation. J. Ind. Eng./Eng. Manag. 2020, 34, 13-28.

3. Gimenez-Fernandez, E.M.; Sandulli, F.D.; Bogers, M. Unpacking liabilities of newness and smallness in innovative start-ups: Investigating the differences in innovation performance between new and older small firms. Res. Policy 2020, 49, 104049. [CrossRef]

4. Dahms, S.; Cabrilo, S.; Kingkaew, S. The role of networks, competencies, and it advancement in innovation performance of foreign-owned subsidiaries. Ind. Market. Manag. 2020, 89, 402-421. [CrossRef]

5. Guo, L.; Zhang, M.Y.; Dodgson, M.; Gann, D.; Cai, H. Seizing windows of opportunity by using technology-building and market-seeking strategies in tandem: Huawei's sustained catch-up in the global market. Asia. Pac. J. Manag. 2019, 36, 849-879. [CrossRef]

6. Drucker, P.F. The Practice of Management; Harper Collins: New York, NY, USA, 2010; p. 37.

7. Zhang, F.; Qiu, W. Mechanism and balance of exploratory and exploitative market-based innovation. J. Manag. Sci. 2013, 26, 1-13.

8. Silva, G.M.; Styles, C.; Lages, L.F. Breakthrough innovation in international business: The impact of tech-innovation and market-innovation on performance. Int. Bus. Rev. 2017, 26, 391-404. [CrossRef]

9. Low, S.; Ullah, F.; Shirowzhan, S.; Sepasgozar, S.M.E.; Lee, C.L. Smart digital marketing capabilities for sustainable property development: A case of Malaysia. Sustainability 2020, 12, 5402. [CrossRef]

10. Chen, X.; Yu, T. An empirical study of the relationship among marketing capability, technological innovation and market performance: An empirial investigation based on the listed SMEs in China. Stud. Sci. Sci. 2013, 31, 585-595.

11. $\mathrm{Li}, \mathrm{X}$. The relationship among dynamic marketing capabilities, customer value innovation and organizational performance in context of green entrepreneurship. Soft Sci. 2013, 9, 13. 
12. Xue, J. Research on the effects of technology capabilities and marketing capabilities on innovation performance of green enterprises: The mediating roles of green exploration and green exploitation. J. South China Norm. Univ. (Soc. Sci. Ed.) 2017, 3, 8.

13. Ngo, L.V.; Bucic, T.; Sinha, A.; Lu, V.N. Effective sense-and-respond strategies: Mediating roles of exploratory and exploitative innovation. J. Bus. Res. 2019, 94, 154-161. [CrossRef]

14. March, J.G. Exploration and exploitation in organizational learning. Organ. Sci. 1991, 2, 71-87. [CrossRef]

15. Arzubiaga, U.; Maseda, A.; Iturralde, T. Exploratory and exploitative innovation in family businesses: The moderating role of the family firm image and family involvement in top management. Rev. Manag. Sci. 2019, 13, 1-31. [CrossRef]

16. Ho, H.; Lu, R. Performance implications of marketing exploitation and exploration: Moderating role of supplier collaboration. J. Bus. Res. 2015, 68, 1026-1034. [CrossRef]

17. $\mathrm{Hu}, \mathrm{H}$.; Wang, Q.; Chen, J. Why do some SMEs explore more while others exploit further? Evidence from Chinese SMEs. Chin. Manag. Stud. 2019, 13, 379-396. [CrossRef]

18. Khan, Z.; Lew, Y.K.; Marinova, S. Exploitative and exploratory innovations in emerging economies: The role of realized absorptive capacity and learning intent. Int. Bus. Rev. 2019, 28, 499-512. [CrossRef]

19. Lin, H.E.; McDonough, E.F., III; Yang, J.; Wang, C. Aligning Knowledge Assets for Exploitation, Exploration, and Ambidexterity: A Study of Companies in High-Tech Parks in China. J. Prod. Innov. Manag. 2017, 34, 122-140. [CrossRef]

20. Tabesh, P.; Vera, D.; Keller, R. Unabsorbed slack resource deployment and exploratory and exploitative innovation: How much does CEO expertise matter? J. Bus. Res. 2019, 94, 65-80. [CrossRef]

21. Wei, Z.; Zhao, J.; Zhang, C. Organizational ambidexterity, market orientation, and firm performance. J. Eng. Technol. Manag. 2014, 33, 134-153. [CrossRef]

22. Ye, X.; Ma, L.; Feng, J.; Cheng, Y.; Liu, Z. Impact of Technology Habitual Domain on Ambidextrous Innovation: Case Study of a Chinese High-Tech Enterprise. Sustainability 2018, 10, 4602. [CrossRef]

23. Zeng, D.; Hu, J.; Ouyang, T. Managing Innovation Paradox in the Sustainable Innovation Ecosystem: A Case Study of Ambidextrous Capability in a Focal Firm. Sustainability 2017, 9, 2091. [CrossRef]

24. Day, G.S. Closing the marketing capabilities gap. J. Mark. 2011, 75, 183-195. [CrossRef]

25. Atuahene-Gima, K. Resolving the capability: Rigidity paradox in new product innovation. J. Mark. 2005, 69, 61-83. [CrossRef]

26. Kyriakopoulos, K.; Moorman, C. Tradeoffs in marketing exploitation and exploration strategies: The overlooked role of market orientation. Int. J. Res. Mark. 2004, 21, 219-240. [CrossRef]

27. Martin, S.L.; Javalgi, R.G.; Cavusgil, E. Marketing capabilities, positional advantage, and performance of born global firms: Contingent effect of ambidextrous innovation. Int. Bus. Rev. 2017, 26, 527-543. [CrossRef]

28. Vorhies, D.W.; Orr, L.M.; Bush, V.D. Improving customer-focused marketing capabilities and firm financial performance via marketing exploration and exploitation. J. Acad. Mark. Sci. 2011, 39, 736-756. [CrossRef]

29. Vorakulpipat, C.; Rezgui, Y. Value creation: The future of knowledge management. Knowl. Eng. Rev. 2008, 23, 283-294. [CrossRef]

30. Chen, H.H.; Kang, H.Y.; Lee, A.H.I.; Chen, S. Strategies, decisions and operations for keeping exploitative and exploratory activities balanced. Knowl. Manag. Res. Pract. 2015, 13, 198-213. [CrossRef]

31. Prajogo, D.I.; Ahmed, P.K. Relationships between innovation stimulus, innovation capacity, and innovation performance. $R$ D Manag. 2006, 36, 499-515. [CrossRef]

32. Ngo, L.V.; O'Cass, A. In search of innovation and customer-related performance superiority: The role of market orientation, marketing capability, and innovation capability interactions. J. Prod. Innov. Manag. 2012, 29, 861-877. [CrossRef]

33. Drechsler, W.; Natter, M.; Leeflang, P.S. Improving marketing's contribution to new product development. J. Prod. Innov. Manag. 2013, 30, 298-315. [CrossRef]

34. Zhou, Y.; Lu, L.; Chang, X. Averting risk or embracing opportunity? Exploring the impact of ambidextrous capabilities on innovation of Chinese firms in internationalization. Cross Cult. Strateg. Manag. 2016, 23, 569-589. [CrossRef]

35. Huang, J.W.; Li, Y.H. The mediating role of ambidextrous capability in learning orientation and new product performance. J. Bus. Ind. Mark. 2017, 32, 613-624. [CrossRef]

36. Mehrabi, H.; Coviello, N.; Ranaweera, C. Ambidextrous marketing capabilities and performance: How and when entrepreneurial orientation makes a difference. Ind. Mark. Manag. 2019, 77, 129-142. [CrossRef]

37. Gok, O.; Peker, S. The impact of marketing's innovation-related capabilities on a firm's innovation performance. Int. J. Innov. Manag. 2020, 24, 2050054. [CrossRef]

38. Falasca, M.; Zhang, J.; Conchar, M.; Li, L. The impact of customer knowledge and marketing dynamic capability on innovation performance: An empirical analysis. J. Bus. Ind. Mark. 2020, 32, 901-912. [CrossRef]

39. Wang, T.; Chen, J. The Research of Effect between Market Orientation and Value-Creation under Turbulence Environment. Nankai Bus. Rev. 2011, 14, 57-66.

40. Peng, Z.; He, P.; Li, Z. Balance of Ambidextrous Marketing Capabilities, Strategic Positional Advantages and New High-tech Service Venture Performance. J. Manag. Sci. 2015, 28, 115-129.

41. Day, G.S. The capabilities of market- driven organizations. J. Mark. 1994, 58, 37-52. [CrossRef]

42. Yalcinkaya, G.; Calantone, R.J.; Griffith, D.A. An Examination of Exploration and Exploitation Capabilities: Implications for Product Innovation and Market Performance. J. Int. Market. 2007, 15, 63-93. [CrossRef]

43. Ozer, M.; Zhang, W. The effects of geographic and network ties on exploitative and exploratory product innovation. Strateg. Manag. J. 2015, 36, 1105-1114. [CrossRef] 
44. Benner, M.J.; Tushman, M.L. Process management and technological innovation: A longitudinal study of the photography and paint industries. Adm. Sci. Q. 2002, 47, 676-706. [CrossRef]

45. Ho, H.; Osiyevskyy, O.; Agarwal, J.; Reza, S. Does ambidexterity in marketing pay off? The role of absorptive capacity. J. Bus. Res. 2020, 110, 65-79. [CrossRef]

46. Kim, N.; Atuahene-Gima, K. Using exploratory and exploitative market learning for new product development. J. Prod. Innov. Manag. 2010, 27, 519-536. [CrossRef]

47. Benner, M.J.; Tushman, M.L. Exploitation, exploration, and process management: The productivity dilemma revisited. Acad. Manag. Rev. 2003, 28, 238-256. [CrossRef]

48. Roan, M.; Mors, M.L. A network perspective on individual-level ambidexterity in organizations. Organ. Sci. 2014, 25, 1860-1877.

49. He, P.; Wang, X.; Li, Z. Market Innovation Key Resources, Market Innovation Mode, Strategic Position Advantages and Corporate Performance. East China Econ. Manag. 2019, 33, 44-53.

50. Xu, H.; Zhang, N.; Feng, Y. Research on growth mode selection mechanism of local brand under the background of transition economy-Based on the Case of Yu Mei Jing. Econ. Manag. 2017, 39, 113-127.

51. Tsai, M.C.; Wang, C. Linking service innovation to firm performance: The roles of ambidextrous innovation and market orientation capability. Chin. Manag. Stud. 2017, 11, 730-750. [CrossRef]

52. Xu, H.; Xu, S.; Feng, Y. The model and path of ambidexterity in emerging internationalization enterprises-A case study from product-market function perspective. Chin. J. Manag. 2014, 11, 1132-1142.

53. Peng, Z.; He, P.; Li, Z. Strategic orientations, ambidextrous marketing activities and service firm performance: The moderating role of market competitive intensity. Econ. Manag. 2015, 37, 75-86.

54. Dong, B.; Yin, L.; Xu, H. Explorative Innovation and New Venture performance: The Combined Moderating role of Multilevel Network Structure. South China J. Econ. 2017, 36, 42-56.

55. Tu, C. Balancing exploration and exploitation capabilities in high technology firms: A multi-source multi-context examination. Ind. Mark. Manag. 2010, 39, 672-680. [CrossRef]

56. Gibson, C.B.; Birkinshaw, J. The antecedents, consequences, and mediating role of organizational ambidexterity. Acad. Manag. J. 2004, 47, 209-226.

57. He, Z.; Wong, P. Exploration vs. exploitation: An empirical test of the ambidexterity hypothesis. Organ Sci. 2004, 15, 481-494. [CrossRef]

58. Lubatkin, M.H.; Simsek, Z.; Ling, Y.; Veiga, J.F. Ambidexterity and performance in small- to medium-sized firms: The pivotal role of top management team behavioral integration. J. Manag. 2006, 32, 646-672. [CrossRef]

59. Cho, M.; Bonn, M.A.; Han, S.J. Innovation ambidexterity: Balancing exploitation and exploration for startup and established restaurants and impacts upon performance. Ind. Innov. 2020, 27, 340-362. [CrossRef]

60. Rothaermel, F.; Deeds, D.L. Exploration and exploitation alliances in biotechnology: A system of new product development. Strateg. Manag. J. 2004, 25, 201-221. [CrossRef]

61. Raisch, S.; Birkinshaw, J.; Probst, G.; Tushman, M.L. Organizational ambidexterity: Balancing exploitation and exploration for sustained performance. Organ. Sci. 2009, 20, 685-695. [CrossRef]

62. Auh, S.; Menguc, B. Balancing exploration and exploitation: The moderating role of competitive intensity. J. Bus. Res. 2005, 58, 1652-1661. [CrossRef]

63. Nielsen, B.B.; Gudergan, S. Exploration and exploitation fit and performance in international strategic alliances. Int. Bus. Rev. 2012, 21, 558-574. [CrossRef]

64. Cao, Q.; Gedajlovic, E.; Zhang, H. Unpacking organizational ambidexterity: Dimensions, contingencies, and synergistic effects. Organ Sci. 2009, 20, 781-796. [CrossRef]

65. Wang, X.; Sun, B. Transformational Business Model, Ambidextrous Marketing Capabilities and Value Creation. J. Guangdong Univ. Bus. Stud. 2017, 32, 34-45.

66. Feng, Y.; Xu, H. The impact of market knowledge development on the market adaptability of international enterprises: Based on the perspective of marketing ambidexterity. J. Mark. Sci. 2015, 11, 129-143.

67. Richman, W.L.; Kiesler, S.; Weisband, S.; Drasgow, F. A meta-analytic study of social desirability distortion in computeradministered questionnaires, traditional questionnaires, and interviews. J. Appl. Psychol. 1999, 84, 754-775. [CrossRef]

68. Brislin, R.W. Translation and content analysis of oral and written material. In Handbook of Cross-Cultural Psychology; Triandis, H.C., Berry, J.W., Eds.; Allyn \& Bacon: Boston, MA, USA, 1980; pp. 349-444.

69. Jansen, J.J.P.; Van Den Bosch, F.A.J.; Volberda, H.W. Exploratory innovation, exploitative innovation, and performance: Effects of organizational antecedents and environmental moderators. Manag. Sci. 2006, 52, 1661-1674. [CrossRef]

70. Qian, X.; Yang, Y.; Xu, W. The Position of Firms' Network, the Absorptive Capacity, and the Performance in Innovation. Manag. World 2010, 5, 118-129.

71. Bell, G.G. Clusters, Networks, and Firm Innovativeness. Strateg. Manag. J. 2005, 26, 287-295. [CrossRef]

72. Ritter, T.; Gemüden, H.G. The Impact of a Company's Business Strategy on Its Technological Competence, Network Competence and Innovation Success. J. Bus. Res. 2004, 57, 548-556. [CrossRef]

73. Bentler, P.M.; Bonett, D.G. Significance tests and goodness of fit in the analysis of covariance structures. Psychol. Bull. 1980, 88, 588-606. [CrossRef] 
74. Baron, R.M.; Kenny, D.A. The moderator-mediator variable distinction in social psychological research: Conceptual, strategic, and statistical considerations. J. Pers. Soc. Psychol. 1986, 51, 1173-1182. [CrossRef] [PubMed]

75. Aiken, L.S.; West, S.G. Multiple Regression: Testing and Interpreting Interactions; Sage Publications: New York, NY, USA, 1991.

76. Solís-Molina, M.; Hernández-Espallardo, M.; Rodríguez-Orejuela, A. Performance implications of organizational ambidexterity versus specialization in exploitation or exploration: The role of absorptive capacity. J. Bus. Res. 2018, 91, 181-194. [CrossRef]

77. Junni, P.; Sarala, R.; Taras, V.; Tarba, S. Organizational ambidexterity and performance: A meta-analysis. Acad. Manag. Perspect. 2013, 27, 299-312. [CrossRef]

78. Josephson, B.W.; Johnson, J.L.; Mariadoss, B.J. Strategic marketing ambidexterity: Antecedents and financial consequences. J. Acad. Mark. Sci. 2016, 44, 539-554. [CrossRef]

79. Barney, J. Firm resources and sustained competitive advantage. J. Manag. 1991, 17, 99-120. [CrossRef]

80. Peteraf, M.A. The cornerstones of competitive advantage: A resource-based view. Strat. Manag. J. 1993, 14, 179-191. [CrossRef]

81. Wernerfelt, B. A resource-based view of the firm. Strat. Manag. J. 1984, 5, 171-180. [CrossRef]

82. Gupta, A.K.; Smith, K.G.; Shalley, C.E. The interplay between exploration and exploitation. Acad. Manag. J. 2006, 49, 693-708. [CrossRef]

83. Jansen, J.J.P.; Simsek, Z.; Cao, Q. Ambidexterity and performance in multiunit contexts: Cross-level moderating effects of structural and resource attributes. Strat. Manag. J. 2012, 33, 1286-1303. [CrossRef]

84. Heirati, N.; O'Cass, A.; Sok, P. Identifying the resource conditions that maximize the relationship between ambidexterity and new product performance. J. Bus. Ind. Mark. 2017, 32, 1038-1050. [CrossRef]

85. Hjelmgren, D.; Dubois, A. Organising the interplay between exploitation and exploration: The case of interactive development of an information system. Ind. Mark. Manag. 2013, 42, 96-105. [CrossRef]

86. Medcof, J.W.; Wang, C.H. Does national culture influence exploratory and exploitative innovation? Int. J. Technol. Manag. 2017, 73, 235-253. [CrossRef]

87. Chen, Z.; Huang, S.; Liu, C.; Min, M.; Zhou, L. Fit between Organizational Culture and Innovation Strategy: Implications for Innovation Performance. Sustainability 2018, 10, 3378. [CrossRef]

88. O'Reilly, C.A., III; Tushman, M.A. Organizational ambidexterity in action: How managers explore and exploit. Calif. Manag. Rev. 2011, 53, 5-22. [CrossRef]

89. Markides, C.C. Business model innovation: What can the ambidexterity literature teach us? Acad. Manag. Perspect. 2013, 27, 313-323. [CrossRef] 